\title{
İstanbul Tıp Fakültesi Klinik Nütrisyon ve Mikrobiyota Araştırma Laboratuvarı Bakteriyel Topluluk Analiz Algoritması
}

\section{İstanbul University, İstanbul Faculty of Medicine, Clinical Nutrition and Microbiota Research Laboratory's Bacterial Community Analysis Algorithm}

\author{
Dilek Sever Kaya ${ }^{1}\left(\mathbb{D}\right.$, Bülent Saka $^{2}$
}

1 İstanbul Üniversitesi, İstanbul Tip Fakültesi, Klinik Nütrisyon ve Mikrobiyota Araştırma Laboratuvarı, İstanbul, Türkiye

2 İstanbul Üniversitesi, İstanbul Tip Fakültesi, İç Hastalıkları Anabilim Dalı, İstanbul, Türkiye

ORCID: D.S.K. 0000-0001-9155-935X; B.S. 0000-0001-5404-5579

Corresponding author/Sorumlu yazar: Dilek Sever Kaya,

İstanbul Üniversitesi, İstanbul Tip Fakültesi, Klinik Nütrisyon ve Mikrobiyota Araştırma Laboratuvarı, İstanbul, Türkiye

E-mail: dsever@istanbul.edu.tr

Submitted/Geliş tarihi: 18.09.2020 First Revision Received/Illk revizyon: 30.09.2020 Last Revision Received/Son revizyon: 07.10.2020 Accepted/Kabul Tarihi: 14.10.2020

Citation/Atıf: Sever Kaya D, Saka B. İstanbul University, İstanbul Faculty of Medicine, Clinical Nutrition and Microbiota Research Laboratory's Bacterial Community Analysis Algorithm. Sağlık Bilimlerinde İleri Araştırmalar Dergisi 2020;3(3):157-167.

https://doi.org/10.26650/JARHS2020-792223
ÖZ

Amaç:Bu çalışmada, "Bakteriyel Topluluk Analiz Algoritması" oluşturularak 16S ribozomal RNA (rRNA) Amplikon Dizileme (AD) stratejisine dayalı Yeni Nesil Dizileme Teknolojisi kullanılarak gerçekleştirilen bakteriyel topluluk analizlerinden elde edilen verilerin daha verimli kullanılabilmesi amaçlanmıștır.

Gereç ve Yöntem:Çalışmamızda, 96 insan bağırsak mikrobiyota örneğinin 16S rRNA genlerinin V3-V4 bölgeleri İllumina MiSeq sistemi kullanılarak çift-sonlu dizileme yöntemiyle dizilenmiştir. Biyoinformatik analizler QIIME 2 açık kaynaklı yazılımı ile gerçekleştirilmiştir

Bulgular:16S rRNA AD koşumundaki 96 örneğin tamamının 16S rRNA V3-V4 bölgeleri başarıyla dizilenmiştir. Çalışmanın sonunda toplam okuma $23.42 \mathrm{M}$, kümelenme yoğunluğu $883 \mathrm{~K} / \mathrm{mm}^{2}$, filtreyi geçen küme yoğunluğu $\% 92.13$, kalite skorları ise $>$ Q30 $=\% 76,7$ olarak tespit edilmiştir. Bu çalışmada elde ettiğimiz veriler ve çalışma sürecinde oluşan tecrübe ve bilgi birikimimiz sonucunda laboratuvarımız tarafından bir Bakteriyel Topluluk Analiz Algoritması olușturulmuștur.

Sonuç:"İstanbul Tip Fakültesi, Klinik Nütrisyon ve Mikrobiyota Araştırma Laboratuvarı Bakteriyel Topluluk Analiz Algoritması" laboratuvarımızda gerçekleștirdiğimiz çalışmaların aynı standartlarda ve karşılaştıılabilir olması için kullanılacaktır. Bu algoritmanın ülkemizdeki araștırmacılar için bir referans niteliğinde olacağını düșünmekteyiz. Ayrıca farklı merkezlerin bu algoritmayı kullanmaları durumunda elde edilecek veriler laboratuvarımızın verileriyle ve bu protokolü kullanan ülkemizdeki veya Dünyadaki diğer merkezlerin verileriyle karşılaştırılabilir olacaktır. Bu şekilde ülkemizdeki insan bağırsak mikrobiyotası ile ilgili yapılan çalışmaların veriminin ve elde edilen verilerin değerinin arttırılmasına katkıda bulunmayı hedefliyoruz.

Anahtar Kelimeler:16S rRNA, bağırsak mikrobiyotası, Yeni Nesil Dizileme

\section{ABSTRACT}

Objective:This study aims to more efficiently use the data obtained from a bacterial community analysis performed using next-generation sequencing based on the $16 \mathrm{~S}$ ribosomal RNA (rRNA) amplicon sequencing (AS) strategy by creating a bacterial community analysis algorithm.

Materials and Methods:The V3-V4 16S rRNA hypervariable regions of 96 human gut microbiota samples were sequenced using the Illumina MiSeq system by the paired-end sequencing method. Bioinformatics analysis was performed by the QIIME 2 open-source software.

Results:The V3-V4 16S rRNA hypervariable regions of 96 gut samples were sequenced successfully using $16 \mathrm{~S}$ rRNA AS. At the end of the study, the total reading was $23.42 \mathrm{M}$, the cluster density was $883 \mathrm{~K} / \mathrm{mm} 2$, the cluster density passing the filter was $92.13 \%$, and the quality scores were $>\mathrm{Q} 30=76.7 \%$. Our laboratory created a bacterial community analysis algorithm from the data we have obtained in this study and based on our experience and knowledge during the study process. 
Conclusion: Our bacterial community analysis algorithm will be used to carry out similar studies in our laboratory within the same, comparable standards. We believe that this algorithm will serve as a reference for researchers in Turkey. In addition, if different research centers will use this algorithm, their data will be comparable to those of our laboratory and other centers in our country and the world using the same protocol. In this way, we can help increase the efficiency of studies and the value of the data obtained from the human gut microbiota.

Keywords: $16 \mathrm{~S}$ rRNA, gut microbiota, next-generation sequencing 


\section{GIiRIŞ}

Bilinen en eski canlı formu olan mikroorganizmalar, ekstrem koşullar dahil olmak üzere hemen hemen her koşulda ve çevrede yaşamlarını sürdürebilmektedir. Günümüzde tüm canlıların yaşamının devamlılığı mikroorganizmalara bağlıdır. İnsanlar da yaşamlarının her döneminde çevrelerinde ve vücutlarında bulunan mikroorganizmalarla etkileşim içindedir. Bu etkileşim o kadar yüksektir ki insan, birçok organizmanın (memeli hücresi, bakteri, virus, mantar, parazit) birlikteliğinden oluşan bir supra-organizma olarak tanımlanmaktadır $(1,2)$. Mikroorganizmalar çeşitli çevrelere uyum sağlayarak bu çevrelerin koşullarına özgü topluluklar oluştururlar. Bakteriler, arkealar, mantarlar, viruslar ve protistlerden oluşan ve sıcak su kaynaklarından insan bağırsağına kadar çok çeşitli özel çevrelerde yaşayan bu mikrobiyal topluluklar "Mikrobiyota" olarak adlandirılmaktadır $(3,4)$. İnsan vücudunun oro-nazo-farengeal bölge, deri, gastrointestinal sistem gibi farklı bölgelerinde farklı mikrobiyal topluluklar bulunmaktadır. Bu mikrobiyal toplulukların her biri konakla etkileşim içindedir ve insan sağlığı üzerinde doğrudan etkilidir (5). Örneğin insan bağırsak mikrobiyotası, insan bağırsağının fizyolojik fonksiyonları ve normal anatomik gelişiminin yanısıra beyin, metabolik ve immun sistem gibi diğer organ ve sistemler açısından anahtar rol oynamaktadır. Ayrıca insan bağırsak mikrobiyotasındaki bazı mikroorganizmalar insan sağlığı açısından önemli proteinleri kodlamakta, bazı vitaminleri ve kısa zincirli yağ asitlerini sentezlemekte, ilaçları ve çevresel toksinleri metabolize etmektedir (6). İnsan sağlığı mikrobiyotayla insan vücudu arasında kurulan homeostatik ve dengeli ilişkiyle yakından ilgilidir. Bu kompleks ilişki ve denge bozulduğunda yani mikrobiyal kompozisyon ve aktiviteler normal ve yararlı durumdan anormal ve insan sağlığı için potansiyel zararlı olabilecek duruma geldiğinde disbiyoz olarak adland1rılan durum ortaya çıkar (7). Disbiyoza neden olabilecek çok çeşitli faktörler bulunmaktadır. Örneğin insan bağırsak mikrobiyotasındaki disbiyozun gelişiminde kötü beslenme, antibiyotik kullanımı, stres gibi birçok faktörün etkili olduğu bilinmektedir. $\mathrm{Bu}$ süreçte mikrobiyota kompozisyonunda değişikler meydana gelir ve bu değişimlerin alkol-dişı hepatit, tip 2 diyabet, obezite, atopi, astım, kanser, inflamatuvar bağırsak hastalı̆̆ı, huzursuz bağırsak sendromu, Alzheimer gibi birçok hastalıkla ilişkili olduğu gösterilmiştir $(6,7,8,9)$.

Mikroorganizmaların birbirinden bağımsız olarak düşünemeyeceğimiz çevre, insan ve diğer canlıların sağlığ 1 üzerindeki etkilerinin önemi anlaşıldıkça, özellikle mikrobiyota kompozisyonlarının sistematik ve fonksiyonel olarak tanımlanması bilim dünyasının en önemli ve ilgi çekici konularından biri haline gelmiştir. Mikrobiyal topluluklarda baskın olarak bulunan mikroorganizmalar bakterilerdir (4). Bu nedenle mikrobiyota çalışmaları bakteri toplulukları üzerinde yoğunlaşmaktadır. Bu çalışmalarda genel olarak mikrobiyal topluluklardaki bakterilerin tanımlanmasi, topluluklardaki zenginliklerinin ve yoğunluklarının belirlenmesi, yapısal özelliklerinin tanımlanması, ürettikleri metabolitlerin topluluk içindeki ve dışındaki etkilerinin incelenmesi, konakla veya bulunduğu cansız çevreyle etkileşimlerinin anlaşılması hedeflenmektedir. İnsan mikrobiyotasındaki bakteriyel topluluklarla ilgili de özellikle bağırsak mikrobiyotası üzerinde birçok çalışma yürütülmektedir. İnsanlarda gelişen bağırsak disbiyozunun tedavisi için mikrobiyotadaki zararlı türlerin öldürülmesi, yararlı türlerin aşılanması, immun cevabın uyarılması veya mikrobiyotanın zararlı metabolitlerinin ve aktivitelerinin ilaçlarla zayıflatılması gibi yolların etkili olacağı yönünde görüşler bulunmaktadır ve mikrobiyotanın hastalıkların tanı ve tedavisinde önemli bir rol oynayabileceği örneğin mikrobiyota odaklı terapiler geliştirilebileceği öngörülmektedir (10). Aynı zamanda insan mikrobiyotasının bakteriyel kompozisyonundaki değişimler hastalıklarla ilişkilendirildiği için bu değişimleri ve bakteriyel toplulukların normal yapısını doğru ve hassas şekilde tanımlamak oldukça önemli bir konudur. Dinamik bir yapıya sahip olan insan mikrobiyota kompozisyonunun tanımlanmasıyla bakteriyel toplulukların sağlıkta ve hastalıkta nasıl değiştiği, baskın bakteri gruplarının hangileri olduğu, biyobelirteç olarak yararlanabilecek bakteri grupları veya 
türleri belirlenebilir. Bu konularla ilgili yapılan çok sayıda çalışma bulunmasına rağmen hala sağlıklı insan mikrobiyotası kavramı net değildir ve disbiyozisin hastalıkların nedeni mi yoksa sonucu mu olduğu yönünde araştırmacılar arasında görüş birliği bulunmamaktadır (11). Bakteriyel kompozisyonların tanımlanmasına yönelik yapılan çalışmalar bu konuların aydınlatılmasına da katkı sağlamaktadır.

Mikrobiyal toplulukların kültürden bağımsız tanımlanması, ilk kez 1997 yılında 16S ribozomal RNA (rRNA) geni kullanılarak Sanger dizileme teknolojisiyle gerçekleştirilmiştir. Bundan itibaren 16S rRNA gen dizileme bakteriyel topluluk analizleri için altın standart olarak kabul edilmektedir (12). 1997 yllından günümüze kadar $16 \mathrm{~S}$ rRNA gen dizileme için kullanılan teknolojilerde büyük değişimler olmuştur. Birinci Nesil Dizileme olarak da adlandırılan Sanger Dizileme Teknolojisiyle yapılan 16S rRNA gen dizileme çalışmaları bakteriyel toplulukların analizinde devrim niteliğinde olsa da bu yöntemin klonlama adımına ihtiyaç duyması ve aynı anda birden fazla bakteri dizisinin çalışılamaması önemli sınırlayıcı faktörler arasında yer almaktadır (13). 2005 yılında İkinci Nesil Dizileme veya Yeni Nesil Dizileme (YND) olarak adlandırılan teknolojinin kullanılmaya başlanmasıyla bakteriyel topluluk analizlerinde yeni bir dönem başlamıştır ve karmaşık mikrobiyotaların mikrobiyal çeşitliliğinin analizi için büyük bir avantaj sağlanmıştır (5). Bu teknoloji ile çok sayıda örnekten binlerce dizi aynı anda dizilenebilmekte ve Sanger dizileme teknolojilerindeki sınırlandırmaları ortadan kaldırarak araştırmacılara zaman kazandırmakta, maliyetleri düşürmekte ve yüksek çıktılı veri sunmaktadır. 16S rRNA Amplikon Dizileme (AD) stratejisine dayanan YND teknolojileriyle gerçekleştirilen metagenomik analizler konvansiyonel yöntemlere göre çok daha hassas ve düşük maliyetli olarak bakteriyel toplulukların tanımlanmasını ve karşılaştırılmasını sağlamaktadır (14). 2011 yılında YND teknolojilerine göre daha uzun okuma yapan ve daha yüksek çıktısı olan Üçüncü Nesil Dizileme teknolojisi adı verilen bir dizileme teknolojisi kullanılmaya başlanmıştır. Başlarda maliyet ve okuma hata oranının yüksekliği nedeniyle YND teknolojilerinin gerisinde kalan bu teknoloji yıllar içinde geliştirilerek bu dezavantajlar büyük oranda ortadan kaldırılmıştır. Bu yeni teknoloji ile 16S rRNA geninin tamamı dizilenebildiği için YND teknolojisine göre daha doğru taksonomik ve filogenetik çözünürlük elde edilebilmektedir. Ayrıca daha düşük maliyetle, daha hızlı ve daha yüksek veri çıktısı sağlanmaktadır. Ancak bu teknolojiyle elde edilen verilerin analizi için tasarlanan araçların azlığı, sınırlı kalitede 16S rRNA dizilerinin elde edilmesi (düşük okuma doğruluğu) nedeniyle YND teknolojileri için tasarlanan mevcut analiz araçlarıyla kısıtlı analiz gerçekleştirilebilmesi Üçüncü Nesil Dizileme teknolojisinin önemli sınırlayıcı faktörleridir $(13,15)$. Günümüzde insan mikrobiyotasındaki bakteri topluluklarının analizinde en yaygın olarak 16S rRNA AD stratejisine dayanan YND teknolojileri kullanılmaktadır.

Bu çalışmada, laboratuvarımızda insan bağırsak mikrobiyotasının 16S rRNA AD stratejisine dayalı YND teknolojisi kullanılarak gerçekleştirilen analizleri sonucunda insan bağırsak mikrobiyota çalışmaları için "Bakteriyel Topluluk Analiz Algoritması" oluşturulmuştur. Bu algoritma laboratuvarımızda gerçekleștirdiğimiz çalışmaların aynı standartlarda ve karşılaştırılabilir olması için kullanılacaktır. Ayrıca farklı merkezlerin bu algoritmayı kullanmaları durumunda elde edilecek veriler laboratuvarımızın verileriyle ve bu protokolü kullanan diğer merkezlerin verileriyle karşlaştırılabilir olacaktır. Bu şekilde ülkemizdeki insan bağırsak mikrobiyotası ile ilgili yapılan çalışmaların veriminin ve elde edilen verilerin değerinin arttırılmasina katkıda bulunmayı hedefliyoruz.

\section{GEREÇ VE YÖNTEM}

\section{Örneklerin Toplanması, Ön Hazırlığı ve}

\section{Saklanması}

Bu çalışma için İ.Ü. İstanbul Tip Fakültesi Klinik Araştırmalar Etik Kurulu’ndan (Tarih:12.05.2017, Sayı:09 ) izin alındı. Tüm gönüllülerden yazılı bilgilendirilmiş onam alındı. Dışkı örneklerinin toplanması için uygun steril kaplar kullanıldı. Örnekler laboratuvara mobil soğutucu dolap ile nakledildi. Örnekler laboratuvar tarafından teslim alındıktan sonra etiketlendi ve hassas terazide tartıldı. Seward 
Stomacher (Seward, İngiltere) cihazı ile homojenize edilen örnekler cryo tüplere aktarıldıktan sonra -80 ${ }^{\circ} \mathrm{C}$ soğutucuda DNA izolasyonları gerçekleştirilene kadar saklandi.

\section{Bakteriyel Genomik DNA İzolasyonu}

Homojenize dışkı örneklerinin bakteriyel genomik DNA (gDNA) izolasyonu "QIAamp PowerFecal DNA Isolation Kit (Qiagen, Almanya)” kullanılarak kit protokolünün yönergelerine göre gerçekleştirildi. Elde edilen gDNA örneklerinin jel elektroforez görüntüleri alınarak, spektrofotometrik ve florometrik yolla ölçümleri gerçekleştirildi. Çalışma için yeterli kalite ve miktarda olan DNA örnekleri -20 derece soğutucuda Polimeraz Zincir Reaksiyonu (PZR) analizleri için saklandı.

\section{S rRNA Amplikon Dizileme}

Bu çalışmada 96 örneğin 16S rRNA genlerinin V3-V4 bölgeleri İllumina MiSeq sistemi (Illumina, Kaliforniya, ABD) kullanılarak çift-sonlu dizileme (2x.300 bp) yöntemiyle MiSeq Reagent Kit v3 (600 cycle) (Illumina, Kaliforniya, ABD) kullanılarak dizilendi. Bu yöntemin sırasıly Amplikon PZR, Amplikon PZR ürünlerinin saflaştırılması, İndeks PZR, İndeks PZR ürünlerinin saflaştırılması, Normalizasyon, Kütüphane Denatürasyonu ve Örnek Yükleme aşamaları "İllumina MiSeq sistemi için 16S örnek hazırlama rehberinin" yönergelerine göre gerçekleştirildi (16). Amplikon PZR'da 16S rRNA V3-V4 gen bölgelerinin çoğaltılması için universal primerler (341F-805R) kullanıldı (17). Saflaştırılan Amplikon PZR ürünlerine dizileme adaptörlerinin ve indekslerin (dual index) bağlanması için İndeks PZR işlemi "Nextera XT index primerleri (İllumina, Amerika)" kullanılarak gerçekleştirildi. Saflaştırılan İndeks PZR ürünlerinin çift zincirli DNA miktarı florometrik yöntemle ölçüldü (Qubit 3.0 florometre cihazı-Qubit dsDNA HS (High Sensitivity) Assay Kit ((Life Technologies, İngiltere)). Ölçümleri yapılan örneklerin normalizasyonu gerçekleştirildikten sonra DNA kütüphanelerinden bir havuz (pool) oluşturuldu. $4 \mathrm{nM}$ havuz, $0.2 \mathrm{~N} \mathrm{NaOH}$ 'le denatüre edildikten sonra elde edilen denatüre kütüphane 5 pmol konsantrasyona dilüe edildi ve reagent kartuşa (MiSeq Reagent Kit v3 (600 cycle)) yüklenerek İllumina Miseq sisteminde dizileme işlemi gerçekleştirildi.

\section{Biyoinformatik Analizler}

İllumina MiSeq ile gerçekleştirilen $16 \mathrm{~S}$ rRNA AD koşumundan elde edilen verilerin biyoinformatik analizi "Illumina MiSeq Reporter Software (Illumina, Amerika)" ve "Quantitative Insights Into Microbial Ecology - QIIME 2" açık kaynaklı yazılımı kullanılarak gerçekleştirildi. Taksonomik sınıflandırma için SILVA rRNA veri bankası (SILVA-138) kullanıldı. Alfa ve beta çeşitlilik analizleri QIIME 2 yazılımı kullanılarak gerçekleştirildi.

\section{Bakteriyel Topluluk Analiz Algoritmasının Oluşturulması}

Laboratuvarımızda bakteriyel topluluk analizleri için kullanılan $16 \mathrm{~S}$ rRNA AD yönteminin her aşamasının optimizasyon çalışmaları tamamlandıktan sonra asıl çalışmaya geçilerek $16 \mathrm{~S}$ rRNA AD işlemi gerçekleştirildi. Bu çalışmada elde ettiğimiz tecrübe ve bilgi birikimi sonucunda "İstanbul Üniversitesi İstanbul Tip Fakültesi Klinik Nütrisyon ve Mikrobiyota Araştırma Laboratuvarı Bakteriyel Topluluk Analiz Algoritması" oluşturuldu.

\section{BULGULAR}

İllumina Miseq sisteminde gerçekleştirilen 16S rRNA AD koşumu "Sequence Analysis Viewer (Illumina, Amerika)" programı ile takip edildi. Koşumun sonunda toplam okumanın $23.42 \mathrm{M}$, kümelenme yoğunluğunun $883 \mathrm{~K} / \mathrm{mm}^{2}$, filtreyi geçen küme yoğunluğunun \%92.13, kalite skorlarının ise $>$ Q30 = \%76,7 olduğu görüldü. Örnek başına en yüksek toplam okuma 474.572 iken en düşük toplam okuma 96.611'dir. Çalışmanın sonunda 16S rRNA AD koşumundaki 96 örneğin tamamının 16S rRNA V3-V4 bölgeleri başarıyla dizilendi. MiSeq Reporter tarafından oluşturulan fasta formatındaki fastq dosyaları QIIME 2 yazılımıyla gerçekleştirilen biyoinformatik analizlerde kullanıldı. İlk olarak okumaların kalite kontrolleri gerçekleştirildi. Q skoru 20'nin altında olan düşük kalitedeki okumalar filtrelendi. Çift son- 
lu okumalar birleştirildikten sonra düşük kaliteli ve kimerik diziler uzaklaştırıldı. Ardından temsili İşlevsel Taksonomik Birimler (Operational Taxonomic Unit - OTU) belirlenerek SILVA veri bankasıyla karşılaştırıldı. Bu şekilde tamamlanan taksonomik analiz sonrasında alfa ve beta çeşitlilik ile istatistiksel analizler QIIME 2'nun alt programlarıyla belirlendi.

16S rRNA AD çalışmasının tamamlanmasının ardından bundan sonraki çalışmalarımızın birbiriyle karşılaştırılabilir olması ve farklı merkezlerde yapılan çalışmalara referans olarak birden fazla merkezin verilerinin karşılaştırılabilmesi amacıyla "İstanbul Tip Fakültesi Klinik Nütrisyon ve Mikrobiyota Araştırma Laboratuvarı Bakteriyel Topluluk Analiz Algoritması" oluşturuldu (Şekil 1).

\section{TARTIŞMA}

İstanbul Üniversitesi İstanbul Tip Fakültesi Klinik Nütrisyon ve Mikrobiyota Araştırma Laboratuvarı'nda yapılan insan bağırsak mikrobiyotası bakteriyel topluluk analizleri için $16 \mathrm{~S}$ rRNA AD stratejisine dayalı YND teknolojisini kullanmaktayız ve bu yöntemin tüm aşamalarını hizmet alımı olmaksızın kendi bünyemizde gerçekleştirmekteyiz. 16S rRNA AD stratejisine dayalı YND yöntemi yurtdışında birçok laboratuvarda rutin olarak uygulanmakla birlikte ülkemizde bu konuda çalışan laboratuvar sayısı azdır. Özellikle yöntemin tüm aşamalarını kendi bünyesinde gerçekleştiren laboratuvar sayısı çok sınırlıdır. 16S rRNA AD çalışması için kullanılan sarfların ve cihazların yurt dışından gelmesi yöntemin ülkemizde uygulanmasının maliyetini arttırmaktadır. Ancak örneklerin daha az maliyet için yurt dışına gönderilmesi de güvenlik zaafiyeti oluşturmakta ve bu alanda ülkemizde nitelikli personel yetişmesini zorlaştırmaktadır. Ayrıca ülkemizde insan mikrobiyotası ile ilgili yapılan çalışma sayısı oldukça azdır. Dünyada ise bu konunun çalışıldığı çok sayıda merkez birçok çalışma yürütmektedir. Ülkemizde insan mikrobiyota çalışmalarının sayısının artması, ülkemize özgü verilerin oluşturulmasını sağlarken, mikrobiyota odaklı tanı ve tedavi çalışmaları ile biyobelirteç ve probiyotik olarak kullanılabilecek türlerin tespitine yönelik çalışmalar için de veri sağlayarak literatüre önemli katkılarda bulunacaktır. $\mathrm{Bu}$ nedenlerle ülkemizde yapılan insan mikrobiyota çalışmaları hem ekonomik hem de nitelik açısından oldukça değerlidir. İnsan mikrobiyota çalışmalarında bir başka önemli husus da yüksek emek gerektiren ve mali yükü olan bu çalışmaların verilerinin karşılaştırılabilir olmasıdır. Elde edilen verilerin başka bir çalışmanın verileri ile karşılaştırılabilir olması için her iki çalışmanın da aynı protokolü kullanması gerekmektedir. 16S rRNA AD çalışmalarının hemen hemen her aşaması farklı yaklaşımlarla çalışılabilir. Bu yaklaşımların herhangi birine doğru veya yanlış kavramlarıyla bakamamakla birlikte her yaklaşımın diğerine göre avantajları veya dezavantajları bulunduğunu bilmek gerekir. Bu nedenle özellikle bu alanda yeni çalışmaya başlayan araştırmacıların literatür verilerini esas alarak en güncel ve en çok tercih edilen yöntemleri uygulamaları en doğru karar olacaktır. 16S rRNA AD stratejilerine dayalı YND teknolojisi ile gerçekleştirilen bakteriyel topluluk çalışmalarında kullanılan yöntemlerin tamamı analiz sonuçlarını doğrudan etkilemektedir. Bu nedenle laboratuvarlar kendi içlerinde de verilerin karşılaştırılabilir olması için tüm çalışmalarını aynı standartlarda ve aynı protokolleri uygulayarak gerçekleştirmelidir. Bir başka sorun da bu çalışmaların hizmet alımı şeklinde gerçekleştirilmesidir. Yine çalışma verilerinin karşılaştırılabilir olması için hizmet alımı şeklinin değişmemesi gerekmekte, ek olarak laboratuvar dışındaki uygulamalar kontrol edilemeyeceği için olası hatalar ve yöntem değişiklikleri araştırmacı tarafından kabul edilmiş olmaktadır. Tüm bu nedenlerle laboratuvarımızda yürüttüğümüz çalışmalar doğrultusunda insan bağırsak mikrobiyota çalışmaları için bir "Bakteriyel Topluluk Analiz Algoritması” oluşturduk. Bu algoritmayı hazırlarken kullandığımız yöntemlerin literatürde en çok kullanılan ve refere edilen yöntemler olmasına özen gösterdik. Bu şekilde verilerimizi literatürdeki çalışmalarla karşılaştırma şansımızı arttırmayı hedefledik.

Birçok insan bağırsak mikrobiyota çalışmasında örnekleme ve DNA izolasyon aşamaları en az dikkat edilen aşamalardır. Ancak bu aşamalarda seçilen yöntem ve prosedürler dizileme çıtılarını direkt etkilemektedir. Örnekleme aşamasında örneklerin işleme alınmadan önce ne kadar süre kaç derece sıcaklıkta 


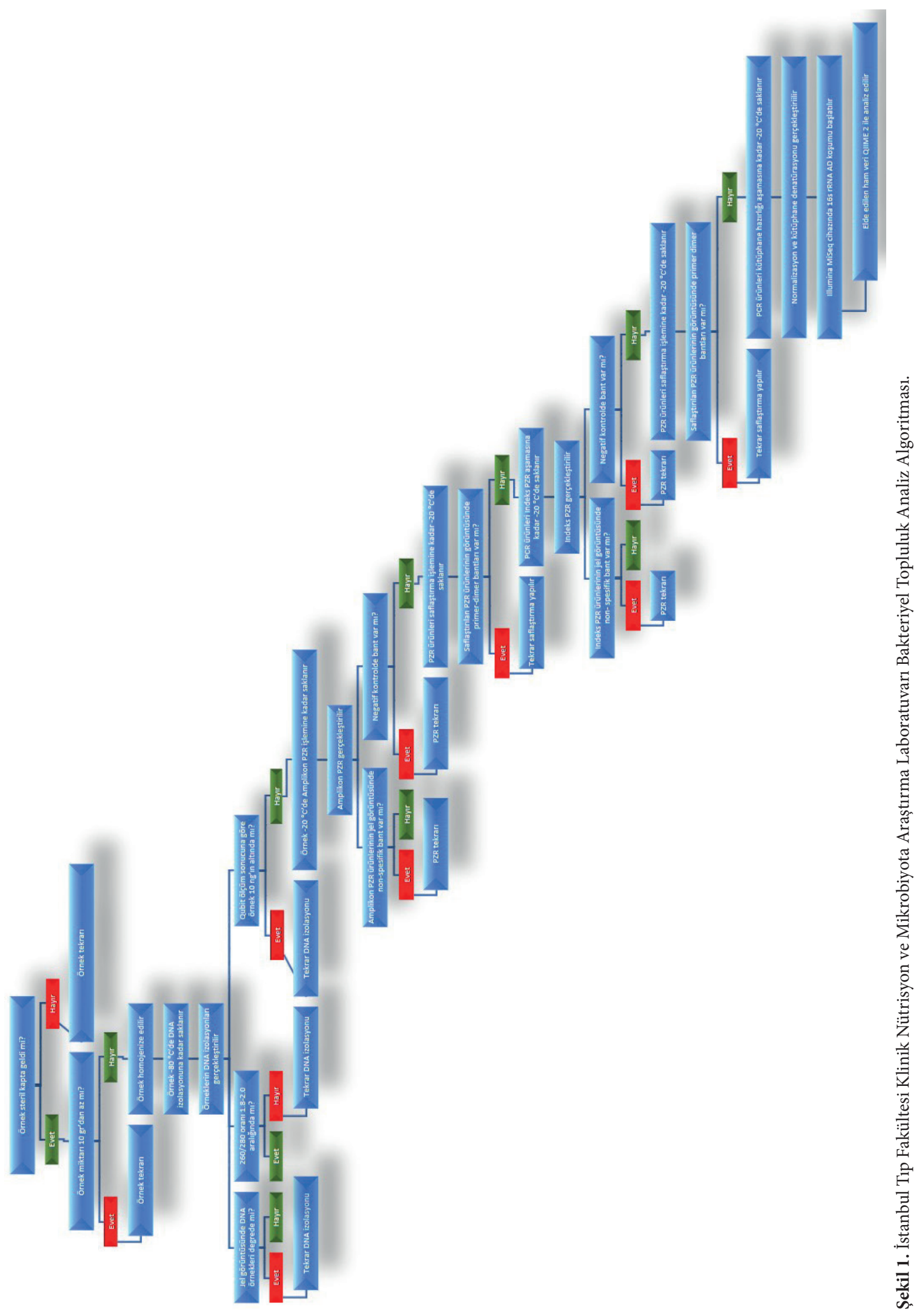

Journal of Advanced Research in Health Sciences, October 2020; Volume 3, Issue 3163 
bekletildiği, örnekler dondurulduysa kaç derecede ne kadar süre bekletildiği ve birden fazla dondurma-çözme işleminin yapılıp yapılmadı̆̆ı, örneklerin DNA izolasyonu veya dondurma işlemleri öncesinde homojenize edilip edilmediği, havayla ne kadar süre temas ettiği ve ne kadar örnek alındığı gibi çeşitli faktörler bakteri çeşitliliğinin tespiti ve $16 \mathrm{~S}$ rRNA AD çıktıları açısından önemlidir $(18,19,20)$. Bu nedenle araştırmacılar çalışmalarını laboratuvar kapasitelerini göz önünde bulundurarak planlamalı, örnekler için uygun saklama ortamını mutlaka sağlamalıdır. Bununla birlikte DNA izolasyon yönteminin seçimi de bakteriyel topluluk yapısının belirlenmesinde önemli bir yer tutar. Bakterilerin hücre yapılarındaki farklılıklar ve feçeste bulunan çeşitli PZR inhibitörleri nedeniyle DNA izolasyon yönteminin hem tüm bakterilerin DNA izolasyonu için uygun olması hem de inhibitörleri ortamdan uzaklaştırabilmesi gerekir. Seçilen DNA izolasyon yöntemi dizileme çıtıları üzerinde olumsuz etkilere ve dolayısıyla mikrobiyal çeşitliliğin hatalı temsiline neden olabilir $(19,21)$. Yapılan çalışmalarda örneklerin saklanma şeklinin, örneğe uygulanan ön işlemlerin ve farklı DNA izolasyon yöntemlerinin metagenomik çalışmaların dizileme çıktılarında farklılıklara neden olduğu gösterilmiştir $(18,19,20,21,22)$. Planlanan çalışmalarda örneklerin aynı yöntemle hazırlanması önemlidir ve özellikle karşılaştırmalı çalışmalarda farklı yöntemle hazırlanan örneklerin analizinde bu durumun göz önünde bulundurulması gereklidir (23). Bu nedenlerle algoritmamızın örnek toplama, ön hazırlık ve saklama adımlarını literatürde en çok tercih edilen yöntemlere göre tasarladık. DNA izolasyon yöntemi içinse yine literatürde en çok kullanılan ticari kitlerden olan QIAamp Power Fecal DNA Isolation Kiti kullanmayı tercih ettik (21).

16S rRNA AD yönteminin gerçekleştirildiği birden fazla YND teknolojisini kullanan platform bulunmaktadır ve her birinin kullandığı teknolojide farklılıklar vardır. Bu platformlardan ilki Roche 454 dizileme sistemidir ve pirodizileme temellidir. Bu sistemin okuma hata oranlarının yüksek olması ve örnek hazırlama prosedürlerinin uzun olması nedeniyle 2013 yılında üretimi durdurulmuştur. Illumina, Ion Torrent, ve SOLiD çalışmalarda sıklıkla tercih edilen diğer
YND platformlarıdır. İon Torrent yarı iletken dizileme teknolojisini kullanırken SOLiD ligasyon yoluyla dizileme yöntemini kullanmaktadır. Illumina ise sentezle dizileme kimyasını katı bir yüzey üzerinde gerçekleşen köprü amplifikasyonu ile birleştirerek kullanır. Bu teknolojiler arasında Illumina platformu özellikle çift-sonlu (paired-end) okuma uzunluğunu arttırmasından sonra daha iyi çıktılar oluşturması ve daha düşük maliyetli olması nedeniyle araştırmacılar tarafından daha çok tercih edilir olmuştur. Dünyada YND çalışmalarının \%90'nından fazlası Illumina platformuyla gerçekleştirilmiştir ve bu platform bir standart haline gelerek lider konuma geçmiştir $(13,24,25,26)$. Bu nedenlerle çalışmalarımızda kullanılacak platformun Illumina olmasına karar verdik.

16S rRNA geninde korunmuş bölgeler içeren ve yüksek derece değişkenlik (hypervariable) gösteren 9 bölge bulunmaktadır. 16S rRNA AD yöntemi genellikle YND dizileme teknolojilerinin sınırlandırmalarından dolayı 16S rRNA geninin değişken bir veya birkaç bölgesinin çoğaltılmasına dayanır. Laboratuvarlar 16S rRNA geninin hedef bölge seçimini literatürde yayınlanan veriler doğrultusunda ve kullandıkları YND teknolojisinin sınırlandırmalarını göz önünde bulundurularak belirlerler. Bakteriyel topluluk çalışmalarımız için bu bölgelerden hedef bölge olarak literatürde en çok tercih edilen, veri bankalarında en çok dizisi bulunan ve Illumina platformuyla gerçekleştirilecek 2 x300 bç çift-sonlu okuma için en uygun hedef bölge olan V3-V4 aşırı değişken bölgeleri seçilmiştir $(25,26,27,28)$.

Bakteriyel topluluk analiz algoritmamızda biyoinformatik analizler için literatürde en çok tercih edilen analiz araçlarından olan QIIME 2 yazılımını ve en güncel veri bankası olan SILVA veri bankasını tercih ettik. Biyoinformatik analizlerde tercih edilen analiz araçlarının ve veri bankalarının birbirleri arasında çeşitli avantaj ve dezavantajları bulunmaktadır ve bu durum analiz sonuçlarını doğrudan etkilemektedir. Bunun yanında bu araçları kullanan araştırmacıların analizlerdeki yöntem tercihleri de analiz sonuçlarında farklılıklara neden olmaktadır (29,30). Bununla birlikte $16 \mathrm{~S}$ rRNA AD koşumu gerçekleştirilip ham veri elde edildikten sonra araştırmacı bu verileri istediği kadar araçla analiz edip istediği veri bankalarıyla kar- 
şılaştırma şansına sahiptir. Biyoinformatik analizler deneysel aşamalar gibi geri dönüşümsüz değildir. Birden fazla analiz yöntemi kullanıp kullanmamak araştırmacının elindedir. Ancak bu şekilde bir çalışma için harcanan zaman ve emek yanında farklı veri bankalarından elde edilen verilerin karşılaştırılamaması, farklı analiz araçlarının verilerinin karşılaştırılma güçlüğü düşünüldügünde tek bir analiz stratejisi üzerinde yoğunlaşmak daha doğru bir yaklaşım olacaktır.

Sonuç olarak 16S rRNA AD çalışması için yöntemleri belirledikten sonra laboratuvarımızda bu yöntemlerin optimizasyon çalışmalarını tamamladık. Ardından 16S rRNA AD çalışmasını başarıyla tamamladık ve bu çalışma doğrultusunda "İstanbul Üniversitesi İstanbul Tip Fakültesi Klinik Nütrisyon ve Mikrobiyota Araştırma Laboratuvarı Bakteriyel Topluluk Analiz Algoritmasını" oluşturduk. Bu algoritmanın ülkemizdeki araştırmacılar için bir referans niteliğinde olacağını düşünmekteyiz. Ayrıca araştırmacılar bu algoritmayı çalışmalarında uyguladıkları takdirde elde ettikleri verilerle laboratuvarımızdaki veriler karşılaştırılabileceği için ülkemizde az sayıda gerçekleştirilen insan bağırsak mikrobiyota çalışmalarının ve elde edilen verilerin daha değerli hale gelmesine katkıda bulunmayı hedefliyoruz. Bununla birlikte oluşturduğumuz 'Bakteriyel Topluluk Analiz Algoritması' dünyada en çok kullanılan yöntemler göz önünde bulundurularak hazırlandığı için bu algoritmayı kullanan araştırmacılar verilerini literatürdeki pek çok çalışmayla da karşılaştırma imkanına sahip olacaktır. Ek olarak bu çalışmada, YND teknolojisi kullanılarak gerçekleştirilen 16S rRNA amplikon dizileme yönteminin temelleri ile literatürde en çok tercih edilen uygulama şekli ve veri analiz yöntemleri hakkında bilgi verilmektedir. Bu şekilde ülkemizde daha fazla araştırmacının bu konuya ilgi duymasını sağlayarak, bu konuda yapılacak çalışmaların artmasına da katkıda bulunmayı hedefliyoruz.

Hakem Değerlendirmesi:Dış bağımsız.

Peer Review:Externally peer-reviewed.

Etik Komite Onayı:Bu çalışma için etik komite onayı İstanbul Üniversitesi İstanbul Tip Fakültesi Klinik Araştırmalar Etik Kurulu'ndan alınmıştır (tarih 12.05.2017 ve no 09).
Ethics Committee Approval:This study was approved by the Istanbul Medical Faculty Clinical Research Ethics Committee. (date 12.05.2017 and number 09).

Bilgilendirilmiş Onam:Katılımcılardan bilgilendirilmiş onam alınmıştır.

Informed Consent:Written consent was obtained from the participants.

Yazar Katkıları:Çalışma Konsepti/Tasarım- D.S.K, B.S.;Veri Toplama- D.S.K, B.S.;Veri Analizi/Yorumlama- D.S.K, B.S.;Yazı Taslağı- D.S.K, B.S.;İçeriğin Eleştirel İncelemesi- B.S.;Son Onay ve SorumlulukD.S.K, B.S.

Author Contributions:Conception/Design of Study- D.S.K, B.S.;Data Acquisition- D.S.K, B.S.;Data Analysis/Interpretation- D.S.K, B.S.;Drafting Manuscript- D.S.K, B.S.;Critical Revision of ManuscriptB.S.;Final Approval and Accountability- D.S.K, B.S

Çıkar Çatışması:Yazarlar çıkar çatışması beyan etmemişlerdir

Conflict of Interest:Authors declared no conflict of interest.

Finansal Destek:Bu çalışma, İstanbul Üniversitesi Bilimsel Araştırma Projeleri Birimi (BAP) tarafından desteklenmiştir. (Proje No:25863)

Financial Disclosure:This study was supported by Istanbul University Scientific Research Projects Unit (BAP). (Project No:25863)

\section{KAYNAKLAR/REFERENCES}

1. Glendinning L, Free A. Supra-organismal interactions in the human intestine. Front Cell Infect Microbiol 2014;4(47):1-4.

2. Kramer P, Bressan P. Humans as Superorganisms:How Microbes, Viruses, Imprinted Genes, and Other Selfish Entities Shape Our Behavior. Perspect Psychol Sci 2015;10(4):464-81.

3. D'Argenio V, Salvatore F. The role of the gut microbiome in the healthy adult status. Clin Chim Acta 2015;451:97-102.

4. Conrad R, Vlassov AV. The Human Microbiota:Composition, Functions, and Therapeutic Potential. Med Sci Rev 2015;2:92-103.

5. Sankar SA, Lagier JC, Pontarotti P, Raoult D, Fournier P. E. The human gut microbiome, a 
taxonomic conundrum. Syst Appl Microbiol 2015;38(4):276-86.

6. Mandal RS, Saha S, Das S. Metagenomic surveys of gut microbiota. Genom Proteom Bioinform 2015;13:148-58.

7. Carding S, Verbeke K, Vipond DT, Corfe, B. $\mathrm{M}$, Owen LJ. Dysbiosis of the gut microbiota in disease. Microb Ecol Health Dis 2015;26:26191.

8. Alkasir R, Li J, Li X, Jin M, Zhu B. Human gut microbiota:the links with dementia development. Protein Cell 2017;8:90-102.

9. Baothman OA, Zamzami MA, Taher I, Abubaker $\mathrm{J}$, Abu-Farha M. The role of gut microbiota in the development of obesity and diabetes. Lipids Health Dis 2016;15:108.

10. Walker AW, Lawley TD. Therapeutic modulation of intestinal dysbiosis. Pharmacol Res 2013;69(1):75-86.

11. Almeida C, Oliveira R, Soares R, Barata, P. Influence of gut microbiota dysbiosis on brain function:a systematic review. Porto Biomed J 2020;5:2.

12. Pace NR. A molecular view of microbial diversity and the biosphere. Science 1997;276:734-40.

13. Santos A, Aerle RV, Barrientos L, MartinezUrtaza J. Computational methods for $16 \mathrm{~S}$ metabarcoding studies using Nanopore sequencing data. Computational and Structural Biotechnology Journal 2020;18:296-305.

14. Malla MA, Dubey A, Kumar A, Yadav S, Hashem A, Abd_Allah EF. Exploring the Human Microbiome:The Potential Future Role of Next Generation Sequencing in Disease Diagnosis and Treatment. Front Immunol 2018;9:2868.

15. Nygaard AB, Tunsjø HS, Meisal R, Charnock C. A preliminary study on the potential of Nanopore MinION and Illumina MiSeq $16 \mathrm{~S}$ rRNA gene sequencing to characterize building-dust microbiomes. Scientific Reports 2020;10:3209.

16.16S Metagenomic Sequencing Library Preparation. Part \# 15044223 Rev. B. Available from:https://support.illumina. com/documents/documentation/chemistry_ documentation/16s/16s-metagenomic-libraryprep-guide-15044223-b.pdf

17. Klindworth A, Pruesse E, Schweer T, Peplles J, Quast C, Horn M, Glöckner FO. Evaluation of general 16S ribosomal RNA gene PCR primers for classical and next-generation sequencing-based diversity studies. Nucleic Acids Res 2013;7:41(1).

18. Hang J, Desai V, Zavaljevski N, Yang Y, Lin X, Satya RV, et al. 16S rRNA gene pyrosequencing of reference and clinical samples and investigation of the temperature stability of microbiome profiles. Microbiome 2014;2:31.

19. Wesolowska-Andersen A, Bahl MI, CarvalhO V, Kristiansen K, Sicheritz-Pontén T, Gupta R, Licht TR. Choice of bacterial DNA extraction method from fecal material influences community structure as evaluated by metagenomic analysis. Microbiome 2014;2:19.

20. Wu GD, Lewis JD, Hoffmann C, Chen Y, Knight $\mathrm{R}$, Bittinger K. Sampling and pyrosequencing methods for characterizing bacterial communities in the human gut using 16S sequence tags. BMC Microbiology 2010;10:206.

21. Hart ML, Meyer A, Johnson PJ, Ericsson AC. Comparative Evaluation of DNA Extraction Methods from Feces of Multiple Host Species for Downstream Next-Generation Sequencing. PLoS One 2015;10:e0143334.

22. Smith B, Li N, Andersen A. S, Slotved H. C, Krogfelt K. A. Optimising Bacterial DNA Extraction from Faecal Samples:Comparison of Three Methods. The Open Microbiology Journal. 2011;5:14-7.

23. Kennedy NA, Walker AW, Berry SH, Duncan $\mathrm{SH}$, Farquarson FM, Louis P, et al. The Impact of Different DNA Extraction Kits and Laboratories upon the Assessment of Human Gut Microbiota Composition by $16 \mathrm{~S}$ rRNA Gene Sequencing. PLoS One 2014;9(2):e88982.

24. Gatew H, Tarekegn GM. Next-generation sequencing platforms for latest livestock reference genome assemblies. Afr J Biotechnol 2018;17(39):1232-40.

25. Sinclair L, Osman O. A, Bertilsson S, Eiler A. Microbial community composition and diversity 
via $16 \mathrm{~S}$ rRNA gene amplicons:Evaluating the illumina platform. PLoS One 2015;10 (2):1-18.

26. Mizrahi-Man O, Davenport ER, Gilad Y. Taxonomic Classification of Bacterial 16S rRNA Genes Using Short Sequencing Reads:Evaluation of Effective Study Designs. PLoS One 2013;8(1):18-23.

27. Petrosino JF, Highlander S, Luna RA, Gibbs RA, Versalovic J. Metagenomic pyrosequencing and microbial identification. Clin Chem 2009;55(5):856-66.

28. García-López R, Cornejo-Granados F, LopezZavala AA, Sánchez-López F, Cota-Huízar A, Sotelo-Mundo RR, et al. Doing More with Less:A Comparison of $16 \mathrm{~S}$ Hypervariable Regions in
Search of Defining the Shrimp Microbiota. Microorganisms 2020;8:134.

29. Marizzoni M, Gurry T, Provasi S, Greub G, Lopizzo N, Ribaldi F. Comparison of Bioinformatics Pipelines and Operating Systems for the Analyses of 16S rRNA Gene Amplicon Sequences in Human Fecal Samples. Frontiers in Microbiology 2020;11:1262.

30. López-Garcíal A, Pineda-Quiroga C, Atxaerandio R, Pérez A, Hernández I, GarcíaRodríguez A, González-Recio O. Comparison of Mothur and QIIME for the Analysis of Rumen Microbiota Composition Based on 16S rRNA Amplicon Sequences. Frontiers in Microbiology 2018;9:3010. 